\title{
Prisão preventiva e standards de prova: propostas para o processo penal brasileiro
}

\author{
Preventive detention and standards of proof: \\ proposals for the Brazilian criminal procedure
}

\section{Caio Badaró Massena ${ }^{1}$}

Universidade de São Paulo - São Paulo/SP, Brasil

caio.badarom@hotmail.com

http://lattes.cnpq.br/1075933426169994

https://orcid.org/0000-0002-9940-9759

Resumo: A partir das recentes discussões no âmbito da epistemologia jurídica, o presente trabalho pretende investigar e propor standards de prova para a decisão que decreta a prisão preventiva do imputado no processo penal brasileiro. Com este objetivo, na primeira parte responderá aos seguintes questionamentos: por que utilizar standards de prova e como formular um standard de prova. A seguir, analisará a relação entre a técnica processual de cognição e os standards probatórios e explicitará a estrutura fático-legal da decisão judicial sobre medidas cautelares pessoais. Finalmente, a partir destes aportes teóricos, somados à análise dos conceitos utilizados pelo legislador e da interpretação dada pela processualística penal brasileira aos dispositivos legais, o estudo proporá standards de prova tanto para o fumus comissi delicti quanto para o periculum libertatis. A metodologia utilizada ao longo do trabalho será a revisão bibliográfica de estudos sobre epistemologia jurídica e direito processual penal.

PalaVRAs-ChaVe: standard de prova; prisão preventiva; prova penal; epistemologia jurídica.

1 Mestrando em Processo Penal na Universidade de São Paulo (USP). Graduado em Direito pela Universidade Federal do Rio de Janeiro (UFRJ). Membro do Instituto de Defesa do Direito de Defesa (IDDD) e do Instituto Brasileiro de Ciências Criminais (IBCCRIM). Advogado. 
ABSTRACT: Based on recent discussions regarding legal epistemology, this paper intends to investigate and propose standards of proof for the decision that decrees preventive detention of the accused in the Brazilian criminal procedure. With this objective, the first part will answer the following questions: why use standards of proof and how to formulate a standard of proof. Next, it will analyze the relationship between procedural technique of cognition and standards of proof and will explain the factual-legal structure of the judicial decision on personal precautionary measures. Finally, based on these theoretical contributions, alongside the analysis of concepts used by the legislator and the interpretation given by legal scholarship to legal provisions, the study will propose standards of proof for both fumus comissi delicti and periculum liberatis. The methodology used throughout the study will be the analysis of bibliography on legal epistemology and criminal procedural law.

KEYWORDS: standard of proof; preventive detention; criminal evidence; legal epistemology.

SUMÁRIO: I. Introdução. II. Por que contar com standards de prova e os requisitos para sua formulação. III. Standards de prova e técnica processual de cognição. IV. Estrutura da decisão que decreta a prisão preventiva. V. Standards de prova e prisão preventiva. V.I. Standards de prova para o fumus comissi delicti. V.II. Standard de prova para o periculum libertatis. VI. Conclusão.

\section{INTRODUÇÃo}

Historicamente, o tema dos standards de prova sempre esteve ligado aos países filiados à tradição do common law. ${ }^{2}$ Nos países de tradição romano-germânica, desde a Revolução Francesa, com a superação da doutrina das provas legais, o princípio da livre valoração da prova tornou-se

2 Cf. WHITMAN, James Q. The origins of reasonable doubt. Theological roots of the criminal trial. Yale University Press: New Heaven-London, 2008; CLERMONT, Kevin M. Standards of decision in law. Psychological and Logical Bases for the Standards of Proof, Here and Abroad. Durham: Carolina Academic Press, 2013. p. 11 e ss. 
a pedra angular dos sistemas de justiça criminal. ${ }^{3}$ Embora não tenha a mesma força com a qual surgiu, o princípio continua exercendo influência normativa, de modo que costumam ser encaradas com desconfiança as regras que pretendem regular a atividade dos juízes diante das provas. ${ }^{4}$

Seja pelo receio de retorno ao sistema de prova legal, seja pela confiança depositada na motivação das decisões pelos juízes e no seu posterior controle pelas instâncias superiores, ${ }^{5}$ o certo é que, nos países de tradição românico-germânica, não houve grande dedicação em estabelecer mecanismos de controle da apreciação das provas pelos juízes e critérios legais de suficiência probatória ao longo dos últimos dois séculos.

É bem verdade que membros da escola clássica italiana já demonstravam inquietação com a liberdade na valoração judicial da prova, ${ }^{6}$ do mesmo modo como é possível encontrar autores, ainda no século passado, preocupados com uma valoração objetiva e racional da prova. ${ }^{7}$ De forma geral, no entanto, a decisão sobre os fatos foi vista unicamente como um produto da consciência dos juízes. ${ }^{8}$

3 Sobre o percurso histórico dos sistemas probatórios, ver: GOMES FILHO, Antonio Magalhães. Direito à prova no processo penal. São Paulo: RT, 1997. p. 17-40.

4 DAMAŠKA, Mirjan R. El derecho probatorio a la deriva (1997). Trad. de Joan Picó i Junoy. Madrid: Marcial Pons, 2015. p. 37-38.

5 HOLLÄNDER, Pavel. Proof and Changing Idea of Truth in Legal Thinking: Reflection on Postmodernism. In: TICHÝ, Luboš (ed.). Standards of Proof in Europe. Alemanha: Mohr Siebeck, 2019. p. 8.

6 ANDRÉS IBÁÑEZ, Perfecto. Vicisitudes e itinerarios de la convicción probatoria en proceso penal. In: Prueba y convicción judicial en el proceso penal. Buenos Aires: Hammurabi, 2009. p. 39-40

7 Por todos, ver: DIAS, Jorge de Figueiredo. Direito Processual Penal (1974). Reimp. Coimbra: Coimbra Editora, 2004. p. 202-203; NOBILI, Massimo. Die freie richterliche Überzeugungsbildung (1974). Trad. de Thomas Vormbaum. Baden-Baden: Nomos Verlagsgesellschaft, 2001. p. 219 e ss.

8 No Brasil, ver: TORNAGHI, Hélio. Instituições de Processo Penal. Vol. 4. Rio de Janeiro: Companhia Editora Forense, 1959. p. 217; MARQUES, José Frederico. Elementos de Direito Processual Penal. Vol. 2. Rio de Janeiro: Companhia Editora Forense, 1961. p. 279; ARANHA, Adalberto José Q. T. de Camargo. Da prova no processo penal (1983). $2^{\text {a }}$ ed. São Paulo: Saraiva, 1987. p. 57-58. No mesmo sentido, embora demonstrando severa preocupação com abusos e arbitrariedades: BARROS, Romeu Pires de Campos. Sistema do Processo Penal Brasileiro. Vol. I: Princípios Fundamentais do Processo Penal. Rio de Janeiro: Forense, 1987. p. 441-445. 
A publicação dos paradigmáticos trabalhos de Luigi Ferrajoli (Diritto e ragione, 1989) e Michele Taruffo (La prova dei fatti giuridici, 1992) contribuiu para uma espécie de «giro epistemológico» no tratamento da prova judicial nos países de civil law, consistente na construção de pontes entre a epistemologia, o direito processual e a filosofia do direito. Este giro levou à elaboração de importantes trabalhos sobre prova judicial na Europa e no Brasil, mas o tema dos standards de prova continuou sendo pouco discutido. ${ }^{9}-10$

Contudo, nos últimos anos, com o que se denominou de boom editorial do discurso probatório, os standards de prova passaram a ser

9 No Brasil, é possível citar, como exceção, alguns trabalhos de Danilo Knijnik, embora o autor não utilize o termo standard probatório (ou de prova): KNIJNIK, Danilo. Os standards do convencimento judicial: paradigmas para o seu possível controle. Revista Forense, v. 97, n.353, p. 15-52, 2001; KNIJNIK, Danilo. A prova nos Juízes Cível, Penal e Tributário. Rio de Janeiro: Editora Forense, 2007. Valendo-se do conceito de standard probatório: BALTAZAR JUNIOR, José Paulo. Standards Probatórios. In: KNIJNIK, Danilo (Org.). Prova Judiciária. Estudos sobre o novo direito probatório. Porto Alegre: Livraria do Advogado, 2007. p. 153-179; BALTAZAR JUNIOR, José Paulo. Standards Probatórios no Processo Penal. Revista Jurídica, v. 363, p. 127-144, 2008.

10 Vale notar o debate travado, já em 2005, entre Laudan, Taruffo, Gascón Abellán e Igartua Salaverría, cujos artigos foram publicados no número 28 da Revista Doxa. Ademais, conforme destaca Paulo de Sousa Mendes, na Europa continental, as exceções à falta de referência aos graus de probabilidade (ou medidas de prova) são os ordenamentos jurídicos escandinavo e italiano (MENDES, Paulo de Sousa. Medida da Prova. In: MENDES, Paulo de Sousa; PEREIRA, Rui Soares (coord.). Prova Penal Teórica e Prática. Coimbra: Almedina, 2019. p. 32). Na Itália, o art. $5^{\circ}$ da Legge 20 febbraio 2006, n. 46, modificou o art. 533 do Codici di Procedura Penale, incluindo a expressão «al di là di ogni ragionevole dubbio». A modificação legislativa, influenciada pela obra Giustizia e modernitá (2001), de Federico Stella, gerou um intenso debate doutrinário na Itália. Nesse sentido, ver: ZAZA, Carlo. Il ragionevole dubbio nella logica della prova penale. Milano: Giuffrè Editore, 2008; CARLIZZI, Gaetano. Libero convincimento e ragionevole dubbio nel processo penale: storia prassi teoria. Bologna: Bonomo Editore, 2018. p. 49 e ss.; CALLARI, Francesco. The defendant's guilt beyond a reasonable doubt in the Italian criminal justice system. Revista Brasileira de Direito Processual Penal, Porto Alegre, vol. 7, n. 2, p. 1227-1260, mai./ago. 2021. 
intensamente debatidos na Europa ${ }^{11}$ e nos países da América Latina. ${ }^{12}$ No Brasil, os juízes e tribunais passaram a se utilizar da expressão ${ }^{13} \mathrm{e}$ a doutrina elaborou importantes estudos sobre a temática. ${ }^{14}$

Em razão talvez da própria unidade do procedimento,${ }^{15}$ a discussão sobre o assunto costuma centrar-se fundamentalmente na decisão de mérito - no processo penal, a decisão de absolvição ou condenação do acusado. No entanto, ao olharmos o fenômeno processual em sua totalidade, notamos diversas decisões específicas que requerem um juízo de suficiência probatória. ${ }^{16}$ É o caso, por exemplo, da decisão que decreta a prisão preventiva do acusado no processo penal.

11 VÁZQUEZ, Carmen (ed.). Estándares de prueba y prueba científica. Ensayos de epistemología jurídica. Madrid: Marcial Pons, 2013; SCHWEIZER, Mark. Beweiswürdigung und Beweismaß: Rationalität und Intuition. Leipzig: Mohr Siebeck, 2015; TICHÝ, Luboš (ed.). Standards of Proof in Europe. Alemanha: Mohr Siebeck, 2019; DEI VECCHI, Diego; CUMIZ, Juan. Estándares de suficiencia probatoria y ponderación de derechos: una aproximación a partir de la jurisprudencia de la Corte Penal Internacional. Madrid: Marcial Pons, 2019; FERRER BELTRÁN, Jordi. Prueba sin convicción: estándares de prueba y debido proceso. Madrid: Marcial Pons, 2021.

12 ORTEGA GOMERO, Santiago (dir.). Proceso, prueba y estándar. Lima: ARA. 2009; PÁEZ, Andrés (coord.). Hechos, evidencia y estándares de prueba. Ensayos de epistemología jurídica. Bogotá: Universidad de los Andes, 2015; PÁEZ, Andrés (ed.). Discusiones XVIII: "Estándares de prueba”, no 18, 2|2016, EDIUNS, 2018.

13 Para uma crítica ao uso pelos operadores jurídicos do «para além de toda a dúvida razoável»: MATIDA, Janaina; VIEIRA, Antonio. Para além do BARD: uma crítica à crescente adoção do standard de prova "para além de toda a dúvida razoável” no processo penal brasileiro. Revista Brasileira de Ciências Criminais, vol. 156, ano 27, p. 221-248, São Paulo, jun. 2019.

14 BADARÓ, Gustavo Henrique. Epistemologia judiciária e prova penal. São Paulo: Editora RT, 2019; PEIXOTO, Ravi. Standards probatórios no direito processual brasileiro. Salvador: JusPodivm, 2021.

15 «A razão da unidade do procedimento está em que todos os seus atos visam a preparar um mesmo ato, dando cada um a sua contribuição para esse fim. No processo jurisdicional, o ato perseguido pelo juiz e pelas partes, a sentença, resume todo o procedimento, constitui o seu resultado e é dotado de eficácia externa.» (FERNANDES, Antonio Scarance. Teoria geral do procedimento e o procedimento no processo penal. São Paulo: Editora RT, 2005. p. 31-32).

16 ANDERSON, Terence; SCHUM, David; TWINING, William. Análisis de la prueba. Trad. coord. por Flavia Carbonell y Claudio Agüero. Madrid: Marcial Pons, 2015. p. 284 e ss. 
A partir da revisão bibliográfica de estudos sobre epistemologia jurídica e direito processual penal, este trabalho pretende justamente analisar os standards de prova necessários para a decretação da prisão preventiva no processo penal brasileiro. Antes, à luz dos recentes debates na doutrina, procuraremos responder aos seguintes questionamentos: por que utilizar standards de prova e como formulá-los? (II). A seguir, será necessário analisar brevemente a relação entre a técnica processual de cognição e os standards probatórios (III). A fim de compreender o nível de suficiência probatória para a decretação da prisão preventiva, será preciso entender o que deve ser provado, motivo pelo qual buscaremos explicitar a construção fático-legal da decisão judicial sobre medidas cautelares pessoais (IV). Finalmente, a partir destes aportes teóricos, procuraremos propor algumas ideias para construção de standards de prova tanto para o fumus comissi delicti (V.I) quanto para o periculum libertatis (V.II).

\section{Por QUe CONTAR COM STANDARDS DE PROVA E OS REQUisitos PARA SUA FORMULAÇÃO.}

A atividade probatória no processo judicial pode ser descrita sob distintas perspectivas, a depender do critério que se adote e do ordenamento jurídico que se tenha como parâmetro. ${ }^{17}$ Para os propósitos deste trabalho, é interessante a classificação de Jordi Ferrer Beltrán, que divide a atividade probatória em três momentos: (i) conformação do acervo probatório; (ii) valoração das provas; (iii) decisão sobre a prova. ${ }^{18}$ A suficiência desta classificação, aqui, decorre da clara distinção entre os momentos de valoração das provas e de adoção da decisão sobre os fatos provados, que evidenciará a necessidade de se utilizar standards de prova.

A fase de valoração das provas consiste na avaliação ao apoio empírico que um conjunto de elementos aporta a uma determinada

17 Para uma ampla análise das distintas fases do procedimento probatório no processo penal brasileiro, ver: VIEIRA, Renato Stanziola. Controle da Prova Penal: Obtenção e Admissibilidade. São Paulo: Editora RT, 2021. p. 81 e ss.

18 FERRER BELTRÁN, Jordi. La valoración racional de la prueba. Madrid: Marcial Pons, 2007. p. 41 e ss. 
hipótese e a outras concorrentes. Esta análise deve ser feita, primeiro, de maneira individual (fiabilidade de cada prova, isoladamente e em relação com outras) e, depois, em conjunto. Além disso, esta fase deve governar-se por regras epistemológicas, isto é, deve submeter-se aos controles de racionalidade geral. ${ }^{19}$

É de se notar, porém, que nunca um conjunto de provas, por maior e relevante que seja, permitirá obter certezas racionais sobre a verdade de uma hipótese, de modo que, no processo judicial, estaremos sempre a falar de um raciocínio probabilístico.$^{20}$ Por isso é que a valoração da prova nunca bastará para tomar uma decisão sobre fatos, porque para isso é necessário dispor de critérios que determinem se o grau de corroboração alcançado é, ou não, suficiente para considerar provada todas ou algumas hipóteses oferecidas. Ao contrário da fase de valoração, a fase de decisão sobre a prova não estará unicamente governada pela epistemologia, mas também por regras jurídicas, que costumam ser de três tipos: as que estabelecem o ônus probatório, as presunções e os standards de prova. ${ }^{21}$

Portanto, os standards de prova são regras que determinam o grau de confirmação que uma hipótese deve atingir, a partir das provas, para poder ser dada como provada e têm como função distribuir o risco de erro entre as partes. À evidência, é uma questão política, e não epistemológica, determinar qual risco de erro nos parece razoável admitir que cada parte suporte em um processo judicial. ${ }^{22}$ Antes de se pensar em determinado nível de exigência para cada decisão, porém, é preciso entender as funções que cumprem os standards de prova, a fim de se decidir sobre a conveniência ou não de os utilizarmos.

A primeira função que um standard de prova cumpre é heurística e justificativa. Deste modo, oferece critérios que devem ser levados em

19 GASCÓN ABELLÁN, Marina. Los hechos en el derecho. Bases argumentales de la prueba. $3^{\text {a }}$ ed. Madrid: Marcial Pons, 2010. p. 144; FERRER BELTRÁN, Jordi. La valoración..., op. cit., p. 45-46.

20 FERRER BELTRÁN, Jordi. La valoración..., op. cit., p. 91 e ss.; TARUFFO, Michele. La prueba de los hechos (1992). Trad. Jordi Ferrer Beltrán. 4ª ed. Madrid: Editorial Trotta, 2011. p. 167 e ss.

21 FERRER BELTRÁN, Jordi. Prueba sin... op. cit, p. 23.

22 FERRER BELTRÁN, Jordi. Prueba sin..., op. cit, p. 24. 
conta no momento da valoração da prova, considerando que a decisão dependerá desses parâmetros (função heurística), e que determinam o grau de suficiência probatória a partir do qual se pode considerar uma hipótese como provada (função justificativa). ${ }^{23}$ Os standards probatórios possibilitam, ainda, o controle da correção do raciocínio probatório pelas instâncias superiores. ${ }^{24}$

A segunda função é de garantia para as partes, pois somente se as partes conhecerem o umbral de suficiência probatória para determinada decisão poderão realizar escolhas racionais antes e durante o processo a respeito da estratégia de defesa de seus interesses. Ademais, a ciência prévia do standard de prova para a condenação no processo penal permitirá à acusação avaliar a solidez da denúncia/queixa que pretende exercer, o que poderia desincentivar acusações sem fundamento. Vale notar, ainda, que a existência de regras que determinem os standards de prova possibilita às partes controlar a correção das decisões, podendo argumentar equívocos na identificação do standard de prova aplicável e, quando identificado corretamente, na sua aplicação. ${ }^{25}$

Por fim, os standards de prova cumprem a função de distribuição do risco de erro entre as partes. Trata-se de uma função complexa, porquanto, em vez de ter um impacto direto na distribuição dos erros, os standards de prova determinam para cada tipo de caso a partir de qual

23 NARDELLI, Marcella Mascarenhas. Presunção de Inocência, Standards de Prova e Racionalidade das Decisões sobre os Fatos no Processo Penal. In: SANTORO, Antonio E. R.; MALAN, Diogo Rudge; MIRZA, Flávio (org.). Crise no Processo Penal Contemporâneo: escritos em homenagem aos 30 anos da Constituição de 1988. Belo Horizonte: D’Plácido, 2018. p. 289-309; GASCÓN ABELLÁN, Marina. Sobre la posibilidad de formular estándares de prueba objetivos. In: VÁZQUEZ, Carmen (coord.). Hechos y Razonamiento Probatorio. México: CEJI, 2018. p. 78-80.

FERRER BELTRÁN, Jordi. Prueba sin..., op. cit, p. 109-112; VASCONCELLOS, Vinicius Gomes de. A prova no processo penal: a importância da valoração do lastro probatório e de seu controle por meio recursal. Revista Eletrônica do Curso de Direito da UFSM, v. 13, n. 2, p. 695-721, 2018. p. 715. Sobre o tema, ver também: TRENTO, Simone. As cortes supremas diante da prova. São Paulo: Thomson Reuters Brasil, 2018.

FERRER BELTRÁN, Jordi. Prueba sin..., op. cit, p. 112-114. 
grau de exigência probatória estamos dispostos a aceitar que o risco de erro recaia sobre a defesa ou sobre o autor. ${ }^{26 \_27}$

Muito embora não se trate de uma função, é de se notar a estreita relação entre standards de prova e a garantia de motivação das decisões judiciais. ${ }^{28}$ Conforme assevera Ferrer Beltrán, sem que tenhamos standards probatórios metodologicamente bem formulados que determinem os umbrais de suficiência probatória de um modo aceitavelmente preciso e de forma subjetivamente controlável, é impossível justificar que o grau de corroboração alcançado por uma hipótese fática à luz das provas apresentadas no processo é suficiente. Dispor de standards de prova e exigir a justificação da decisão a partir das provas apresentadas e dos standards

26 Nas palavras de Laudan, «the raison d'être for a standard of proof is precisely to have a decision rule that will distribute outcomes in accord with their respective costs.» (LAUDAN, Larry. The Law's Flaws. Rethinking Trial and Errors? Milton Keynes: College Publications, 2016. p. 103). No mesmo sentido: FERRER BELTRÁN, Jordi. Prueba sin..., op. cit, p. 115-138; GASCÓN ABELLÁN, Marina. Sobre la posibilidad..., op. cit., p. 70-72.

27 Relativamente à distribuição de erros entre as partes, desde já convém evitar alguns equívocos. Se no processo judicial está em jogo sempre um raciocínio probabilístico no que se refere ao acertamento dos fatos, não há como evitar completamente a possibilidade de erros. No processo penal, para o acusado, $o$ custo do erro na sentença ou na decisão que decreta a prisão preventiva será uma grave intervenção no seu direito fundamental à liberdade, o que deve ser levado em conta. Não existindo, contudo, meio de excluir totalmente a possibilidade de erro, mesmo a adoção do standard de prova mais alto possível representará alguma distribuição de chance de erro. De todo modo, a inevitável distribuição do risco entre as partes em nada se confunde com a relativização no processo penal do ônus da acusação em provar as suas afirmações fáticas, sempre que formular alguma pretensão, como decorrência da presunção de inocência (BINDER, Alberto M. Derecho Procesal Penal. Tomo V. Buenos Aires: Ad-Hoc, 2021. p. 253 e ss.).

28 Sobre um conceito racionalista da motivação das decisões: TARUFFO, Michele. A motivação da sentença civil (1975). Trad. de Daniel Mitidiero, Rafael Abreu e Vitor de Paula Ramos. São Paulo: Marcial Pons, 2015; ANDRÉS IBÁÑEZ, Perfecto. "Carpintaria" da Sentença Penal (em Matéria de "Fatos"). Trad. de Lédio Rosa de Andrade. In: Valoração da Prova e Sentença Penal. Rio de Janeiro: Lumen Juris, 2006. p. 119-162; GOMES FILHO, Antonio Magalhães. A motivação das decisões penais (2001). $2^{\mathrm{a}}$ ed. rev. e atual. São Paulo: Editora RT, 2013. 
aplicáveis são duas condições para escapar da arbitrariedade e tornar possível o devido processo legal. ${ }^{29}$

Como se vê, mais do que dispor de standards de prova, é necessário que eles sejam formulados a partir de uma metodologia adequada, por meio de critérios intersubjetivamente controláveis, que não apelem a elementos subjetivos de quem decide. Do contrário, as três funções mencionadas não se realizarão e o standard de prova não permitirá a fundamentação racional da decisão. É crucial, portanto, entender os requisitos necessários à sua construção.

Deste modo, para que uma regra possa cumprir a função de um standard de prova, deve dar conta de três requisitos: (i) apelar a critérios relativos à capacidade justificativa do acervo probatório a respeito das hipóteses em conflito; (ii) ser capaz de determinar um umbral a partir do qual uma hipótese será considerada provada; (iii) utilizar critérios qualitativos, próprios da probabilidade não matemática. ${ }^{30}$

Com o primeiro requisito, exclui-se o uso de critérios que apelem a elementos subjetivos do juiz. Exige-se, deste modo, que os parâmetros para indicar o grau de exigência probatória requerido sejam relativos ao quanto o acervo probatório apoia objetivamente as distintas hipóteses, e não ao convencimento psicológico do julgador. ${ }^{31}$

29 FERRER BELTRÁN, Jordi. Prueba sin..., op. cit, p. 198.

30 FERRER BELTRÁN, Jordi. Prueba sin..., op. cit, p. 29.

31 FERRER BELTRÁN, Jordi. Prueba sin..., op. cit, p. 29-32. O entendimento de que os standards de prova não devem remeter ao estado psicológico dos juízes e jurados é certamente o motivo principal das críticas às interpretações comumente dadas ao «para além da dúvida razoável». Estas críticas podem ser verificadas em: LAUDAN, Larry. ¿Es razonable la duda razonable? (2003). Trad. de Jose R. Beguelin. In: El estándar de prueba y las garantías en el proceso penal. Buenos Aires: Hammurabi, 2011. p. 119-195. Na doutrina brasileira, encampando estas críticas e opondo-se ao uso deste standard: MATIDA, Janaina; VIEIRA, Antonio. Para além do BARD..., op. cit., p. 222-248. Há na doutrina brasileira também opinião no sentido de que, em ordenamentos jurídicos nos quais o julgamento deve ser realizado com base em critérios racionais, com a obrigatoriedade de fundamentação das decisões judiciais e possibilidade de controle por via recursal, o standard probatório «para além da dúvida razoável» pode aportar importantes contribuições. Neste caso, porém, busca-se definir este standard a partir de «critérios objetivos e racionais, superando uma visão subjetivista que se foca simplesmente no convencimento obtido pelo julgador» (VASCONCELLOS, Vinicius Gomes de. Standard probatório para 
O segundo requisito impõe que o standard de prova deve expressar-se de maneira que indique um umbral de exigência probatória o mais preciso possível, minimizando a imprecisão, que é típica da linguagem ordinária. ${ }^{32}$ Vale notar que a conveniência ou não de se adotar este requisito leva ao debate sobre soluções universalistas ou particularistas. Por fugir ao escopo específico do presente trabalho, não será possível discutir o tema, bastando esclarecer, neste momento, que concordamos com a opinião de Ferrer Beltrán. Para este autor, sob a perspectiva das garantias dos destinatários da decisão, o modo particularista de determinar o nível de suficiência probatória, que deixa a decisão integralmente nas mãos dos juízes e jurados, é incompatível com o Estado de Direito e com o direito à prova como parte do direito ao devido processo legal. ${ }^{33}$

O terceiro requisito reclama que o standard de prova seja construído com base na probabilidade indutiva ou lógica, isto é, não matemática. Este é o modelo que melhor se aplica à estrutura geral do raciocínio probatório no momento da valoração no processo judicial, pois, embora não admita o cálculo matemático, permite a graduação e a comparação

condenação e dúvida razoável no processo penal: análise das possíveis contribuições ao ordenamento brasileiro. Revista Direito GV, v. 16, n. 2, p. 1-26, maio/ago 2020. p. 20). Sem negar, por um lado, o risco do uso retórico e meramente estético que pode advir da expressão e, por outro, a sua potencialidade quando formulados requisitos objetivos e controláveis para caracterizar este standard, mas considerando que a discussão sobre as vantagens e desvantagens da sua utilização poderia transbordar o assunto deste texto, optar-se-á por evitá-la na construção dos standards de prova aqui propostos.

32 LAUDAN, Larry. Por qué un estándar de prueba subjetivo y ambiguo no es un estándar (2005). Trad. de Raul Calvo Soler. In: El estándar de prueba y las garantías en el proceso penal. Buenos Aires: Hammurabi, 2011. p. 57-86; FERRER BELTRÁN, Jordi. Prueba sin..., op. cit, p. 35. Sobre as dificuldades que podem existir para formular um standard de prova objetivo, ver: GONZÁLEZ LAGIER, Daniel. ¿Es posible formular un estándar de prueba preciso y objetivo? Algunas dudas desde un enfoque argumentativo de la prueba. In: FERRER BELTRÁN, Jordi; VÁZQUEZ, Carmen (eds.). El razonamiento probatorio en el proceso judicial. Un encuentro entre diferentes tradiciones. Madrid: Marcial Pons, 2020. p. 426-431.

33 Para um amplo debate sobre o tema: FERRER BELTRÁN, Jordi. Prueba sin..., op. cit, p. 44-65. Em que pese não trate específicamente dos standards de prova, é interesante ver: NANZER, Alberto. La regularidad como derecho individual. Fundamentos para una teoría normativa del proceso penal. Madrid: Marcial Pons, 2021. p. 225 e ss. 
do nível de suporte indutivo com que conta cada hipótese, isto é, permite uma ordenação das hipóteses. ${ }^{34}$

Apesar de não ser exatamente o quarto requisito para a formulação de um standard de prova, Ferrer Beltrán alude ao fato de que todo processo judicial requer vários standards, que devem fixar umbrais de suficiência probatória distintos e progressivos. A questão, aqui, diz respeito à relação entre os distintos standards de prova previstos para as diversas decisões sobre os fatos que são tomadas ao longo do processo. Nesse sentido, entende-se que os standards de prova devem seguir uma tendência geral ascendente. ${ }^{35}$

E isso não porque, do contrário, a decisão inicial consistiria em uma antecipação da decisão final, ${ }^{36}$ mas sim porque não seria razoável, a título de exemplo, para o recebimento da denúncia - antes, portanto, da própria instrução probatória, realizada em contraditório - exigir um standard de prova tão alto quanto aquele exigido para a condenação.

Ademais, considerando a própria função dos standards de prova, é preciso levar em consideração a gravidade do erro para cada tipo de decisão. A prisão preventiva consiste em uma séria intervenção na liberdade do acusado, motivo pelo qual é bastante grave o erro de submeter um inocente a esta medida. ${ }^{37} \mathrm{~A}$ decisão que decreta a prisão preventiva do

34 FERRER BELTRÁN, Jordi. La valoración..., op. cit., p. 97 e 122. Sobre o tema, ver também: COHEN, L. Jonathan. Lo probable y lo demostrable (1977). Trad. de Orión Vargas e Carlo Iván Ruiz. Medellín: Orión Vargas Vélez, 2017; BADARÓ, Gustavo Henrique. Epistemologia..., op. cit., p. 224 e ss.

35 FERRER BELTRÁN, Jordi. Prueba sin..., op. cit, p. 102.

36 Como bem pontua Ferrer Beltrán: «Aunque dos decisiones compartan un mismo estándar de prueba, no necesariamente la decisión justificada debe ser la misma. Ello depende de cuáles sean las pruebas disponibles y la información que ellas aporten. Puede suceder perfectamente que en un momento $t_{1}$ el acervo probatorio sea menor que en un momento $t_{2}$, o que aún no se hayan practicado algunas pruebas y, por tanto, la cantidad y calidad de la información aportada por las mismas sea muy distinta. En esa situación, aunque las dos decisiones se tomen con el mismo estándar de prueba, nada impone que al adoptar la primera ya estemos anticipando la segunda» (FERRER BELTRÁN, Jordi. Prueba sin..., op. cit, p. 102).

37 FERRER BELTRÁN, Jordi. Prueba sin..., op. cit, p. 103-105. A gravidade da intervenção em direitos fundamentais do acusado, no caso de prisão preventiva, é tamanha ao ponto de alguns autores defenderem a sua absoluta ilegitimidade e extinção. Nesse sentido, com ampla indicação bibliográfica: 
acusado distingue-se substancialmente daquela que, por exemplo, recebe a denúncia. Nada obstante a prisão preventiva possa ser decretada antes do recebimento da denúncia, é razoável que se exija um grau de suficiência probatória bastante alto, em contraposição à tendência geral de ascendência.

Explicitadas as razões para se adotar regras que definam standards de prova e os requisitos para formulá-los, estaríamos em condições de ingressar no tema de nosso interesse: os standards de prova para a decisão que decreta a prisão preventiva do acusado no processo penal brasileiro. Antes disso, a fim de afastar alguns equívocos, convém analisar, ainda que em linhas gerais, a relação entre a técnica processual de cognição e os standards de prova.

\section{Standards de PRova e técnica PRocessual de Cognição.}

Em uma das mais conhecidas tentativas de sistematização das atividades cautelares desenvolvidas por meio do processo judicial (civil), Piero Calamandrei asseverava que, para cumprir a função de prevenção urgente, as providências cautelares devem contentar-se, em lugar da certeza, com a aparência do direito, que pode resultar de uma cognição muito mais rápida e superficial que a ordinária: summaria cognitio. ${ }^{38}$

Nesse sentido, Calamandrei argumentou que, relativamente à investigação sobre o direito (a ser tutelado na providência principal), a cognição sumária se limita em todos os casos a um juízo de probabilidade e de verossimilhança: «en sede cautelar basta que la existencia del derecho aparezca verosímil». ${ }^{39}$ Por outro lado, no que diz respeito ao perigo de que o direito aparente não seja satisfeito, o autor destacou duas possibilidades: na primeira, haveria a possibilidade de declaração de certeza do perigo, realizada de modo pleno e profundo; na segunda, a declaração de certeza se realizaria em dois tempos: conhecimento sumário em um primeiro momento (inaudita altera parte), ordinário em

VITALE, Gustavo L. Encarcelamiento de presuntos inocentes. Hacia la abolición de una barbarie. Buenos Aires: Hammurabi, 2007.

38 CALAMANDREI, Piero. Introducción al estudio sistemático de las providencias cautelares (1936). Argentina: Ediciones Olejnik, 2018. p. 77.

39 CALAMANDREI, Piero. Introducción al estudio..., op. cit., p. 77. 
um segundo (convalidação). ${ }^{40}$ Em geral, nos países da América Latina, o pensamento de Calamandrei foi determinante, tendo influenciado tanto a doutrina quanto a jurisprudência brasileiras, ${ }^{41}$ motivo pelo qual convém nos determos aos conceitos de cognição e às categorias de probabilidade, verossimilhança e certeza.

Entre nós, Kazuo Watanabe foi o responsável por buscar a sistematização da técnica processual de cognição. ${ }^{42}$ Nas palavras de Watanabe:

«[...] a cognição pode ser vista em dois planos distintos: horizontal (extensão, amplitude) e vertical (profundidade). No plano horizontal, a cognição tem por limite os elementos objetivos do processo [...]. Nesse plano, a cognição pode ser plena ou limitada (ou parcial), segundo a extensão permitida. No plano vertical, a cognição pode ser classificada segundo o grau de sua profundidade, em exauriente (completa) e sumária (incompleta).» ${ }^{43}$

40 CALAMANDREI, Piero. Introducción al estudio..., op. cit., p. 79-80.

41 MITIDIERO, Daniel. Antecipação da Tutela: da tutela cautelar à técnica antecipatória (2013). $4^{\mathrm{a}}$ ed. São Paulo: Editora RT, 2019. p. 43-44. A influência de Calamandrei na doutrina brasileira de processo civil sem dúvida se refletiu na processualística penal. O processo penal brasileiro, ao longo do último século, foi pensado a partir das categorias do processo civil, no seio da conhecida «teoria geral do processo», e o tema das providências cautelares não fugiu a essa tendência (nesse sentido, ver: BARROS, Romeu Pires de Campos. Processo Penal Cautelar (1982). 2a ed. Brasília: Gazeta Jurídica, 2017). Muito embora a impossibilidade de realizar certas analogias com as medidas cautelares do processo seja destacada há décadas pela doutrina (GOMES FILHO, Antonio Magalhães. Presunção de inocência e prisão cautelar. São Paulo: Saraiva, 1991. p. 57), é sintomática a insistência no uso de um «poder geral de cautela» por parte dos tribunais e juízes brasileiros, que, como destacado recentemente pelo Min. Celso de Mello, não existe no processo penal (HC 186.421/SC. $2^{\text {a }}$ Turma do STF. Rel.: Min. Celso de Mello. Julgamento em: 20 de outubro de 2020).

Sobre o uso do termo técnica processual, Watanabe esclarece: «[a]o falarmos em "técnica processual”, todavia, pretendemos aludir, não à cognição considerada em si, estaticamente, e, sim, à cognição utilizada de diferentes modos, dinamicamente, na concepção de processos diferenciados e ajustados às variadas exigências do direito e pretensão material, vale dizer, à instrumentalidade da cognição no plano das opções técnicas e políticas do legislador processual.» (WATANABE, Kazuo. Da cognição no processo civil (1987). $2^{\mathrm{a}}$ ed. atual. Campinas: Bookseller, 2000. p. 18).

WATANABE, Kazuo. Da cognição..., op. cit., p. 111-112. 
Para os fins deste trabalho interessa compreender a cognição no plano vertical. A cognição exauriente, portanto, propiciaria um juízo com índice de segurança maior em relação à certeza do direito controvertido. ${ }^{44}$ Quanto à cognição sumária, Watanabe esclarece se tratar de uma cognição superficial, menos aprofundada no sentido vertical, e apresenta a opinião de distintos processualistas, os quais se valem das categorias probabilidade, verossimilhança e credibilidade. Em seguida, o autor manifesta preferência pelas terminologias utilizadas por Calamandrei (probabilidade e verossimilhança) e alerta para o fato de que, em razão da função que cumpre a cognição sumária, o grau máximo de probabilidade é excessivo. ${ }^{45}$

Nota-se que Watanabe, ao trabalhar com as categorias empregadas por Calamandrei, recai no mesmo erro do processualista italiano. A certeza refere-se a um mero estado subjetivo ${ }^{46}$ e se sabe, hoje, que um conjunto de provas, por maior e relevante que seja, nunca permitirá obter certezas racionais sobre a verdade de uma hipótese ${ }^{47}$. Por sua vez, a verossimilhança diz respeito à plausibilidade de uma hipótese segundo a normalidade das coisas (id quod plerumque accidit), em uma situação em que essa asserção não tenha sido submetida à verificação probatória ou demonstrativa. Como destaca Taruffo, a verossimilhança prescinde dos elementos de prova. ${ }^{48}$ No limite, o conhecimento no processo judicial será sempre probabilístico, como visto acima.

Bem compreendidas as críticas acima, é necessário definir no que consiste exatamente a cognição sumária, ao menos em relação às hipóteses probatórias a serem estabelecidas nas decisões fundadas neste modo de cognição. Nesse ponto, concordamos com o posicionamento de que a principal diferença entre a decisão fundada em cognição sumária

44 WATANABE, Kazuo. Da cognição..., op. cit., p. 113.

45 WATANABE, Kazuo. Da cognição..., op. cit., p. 125-128.

46 Sobre esta categoria, de forma crítica, ver: TARUFFO, Michele. Uma simples verdade: o juiz e a construção dos fatos (2009). Trad. de Vitor de Paula Ramos. São Paulo: Marcial Pons, 2016. p. 108-111. Sobre o tema, ver também: FERRER BELTRÁN, Jordi. Prova e verdade no direito (2003). Trad. de Vitor de Paula Ramos. São Paulo: Editora RT, 2017. p. 86-95.

47 FERRER BELTRÁN, Jordi. La valoración..., op. cit., p. 91.

48 TARUFFO, Michele. La prueba de los hechos (1992). Trad. Jordi Ferrer Beltrán. $4^{\mathrm{a}}$ ed. Madrid: Editorial Trotta, 2011. p. 183-190. 
e aquela fundada em cognição exauriente consiste na presença da maior oportunidade do contraditório na segunda. ${ }^{49}$

Se é certo que nem sempre o contraditório implicará produção e exame de novos elementos probatórios na cognição exauriente, ${ }^{50}$ não há como desconsiderar que, ao menos tendencialmente, provimentos provisórios baseados em cognição sumária lidam com quadros probatórios incompletos. ${ }^{51}$ Por este motivo como já abordado, é razoável não se exigir um standard de prova tão alto quanto aquele requerido para a sentença.

Em suma, as próprias categorias utilizadas por Watanabe levaram-no a pensar a distinção entre cognição sumária e exauriente a partir da distinção entre probabilidade/verossimilhança e certeza, desconsiderando que a decisão judicial sempre trabalha com graus de probabilidade. Por esse motivo, em sua obra, paradigmática na doutrina brasileira, não fica claro no que consiste a superficialidade característica da cognição sumária. Não raro, essa superficialidade é confundida como uma renúncia à confirmação das alegações da parte. A nosso ver, na cognição sumária, em virtude da ausência de contraditório, o quadro probatório tende a ser menos completo, motivo pelo qual é razoável que o standard de prova exija um determinado patamar de suficiência probatória menor do que o pensado para a decisão final.

Em relação à prisão preventiva, somam-se outros dois fatores: (i) em regra, a medida é decretada antes da instrução processual (o que reforça a conclusão anterior); (ii) a prisão preventiva consiste em uma séria intervenção na liberdade do acusado, sendo bastante grave o erro de submeter um inocente a esta medida (o que atenua a tendência ascendente dos standards de prova).

Com efeito, convém ainda reter duas ideias já destacadas por Calamandrei que nos parecem interessantes para os fins deste trabalho. A primeira é a de que, em relação ao requisito de perigo para as providências cautelares, que no processo penal é entendido como periculum libertatis,

\footnotetext{
49 Nesse sentido, ver: SCHENK, Leonardo Faria. Cognição sumária: limites impostos pelo contraditório no processo civil. São Paulo: Saraiva, 2013; PEIXOTO, Ravi. Standards..., op. cit., p. 295.

50 PEIXOTO, Ravi. Standards..., op. cit., p. 295-296.

51 MITIDIERO, Daniel. Antecipação..., op. cit., p. 124.
} 
a cognição deve ser realizada de modo pleno e profundo. A segunda é a possibilidade de realizar-se, dentro do procedimento cautelar, um juízo em «dois tempos», o que a nosso ver pode ser interessante tanto para definição do periculum libertatis quanto para a caracterização do fumus comissi delicti.

\section{Estrutura dA DECISÃo QUE DECRETA A PRISÃo PREVENTIVA.}

A temática da cautelaridade no processo penal, mormente no que se refere à prisão preventiva, é espinhosa e carece de conceituação unívoca pela doutrina. Apesar da enorme relevância do debate, foge ao escopo do trabalho as discussões sobre a constitucionalidade e convencionalidade da prisão preventiva como garantia da ordem pública e da ordem econômica e para evitar a reiteração delitiva. ${ }^{52}$

Interessa-nos aqui a estrutura fático-jurídica da decisão judicial sobre medidas cautelares pessoais. Para tanto, utilizaremos como base a interessante proposta de Maurício Zanoide de Moraes, que afirma, a nosso ver com acerto, que esta decisão deve ter partes internas pré-definidas e de explicação judicial obrigatória, com seus respectivos conteúdos vinculados a atender, no caso concreto, as exigências legais específicas. ${ }^{53}{ }^{54}$

52 Acerca destes assuntos, ver, por todos: PRADO, Geraldo. Excepcionalidade da prisão provisória. In: FERNANDES, Og (coord.). Medidas Cautelares no Processo Penal: Prisões e suas alternativas. Comentários à Lei 12.403, de 04.05.2011. São Paulo: Editora RT, 2011. p. 101-204; GOMES FILHO, Antonio Magalhães. Presunção..., op. cit, p. 66-69; PALACIOS MOSQUERA, Luis Blaimir. Detención preventiva y control de convencionalidad: el "peligro para la comunidad" desde la perspectiva del Sistema Interamericano de Derechos Humanos. Bogotá: Grupo Editorial Ibáñez, 2018.

53 MORAES, Maurício Zanoide. Decisão judicial e medidas cautelares pessoais: em busca de um modelo decisório ideal. In: VAZ, Denise Provasi et al. (orgs.). Eficiência e garantismo no processo penal: estudos em homenagem a Antonio Scarance Fernandes. São Paulo: LiberArs, 2017. p. 295.

54 Vale notar que há alguns anos os tribunais superiores brasileiros vêm entendendo pela necessidade de motivação concreta para a decretação da prisão preventiva, não bastando a menção à gravidade abstrata do tipo penal ou a citação genérica das hipóteses legais autorizadoras da medida (a título de exemplo, ver: HC 98.673/SP. Segunda Turma do Supremo Tribunal Federal. Rel.: Min. Ellen Gracie. Julgamento em: 06 de outubro de 2009; HC 99.043/ PE. Segunda Turma do Supremo Tribunal Federal. Rel.: Min. Gilmar Mendes. Julgamento em: 24 de agosto de 2010; HC 118.039/MA. Primeira Turma 
Quanto à estrutura interna, o autor assevera que a decisão deve estar voltada a atender, de maneira direta, aos itens relativos ao fumus comissi delicti e ao periculum libertatis. Em relação ao primeiro, deve prevalecer a constatação objetiva dos fatos demonstrados no procedimento/processo e, quanto ao segundo, deve predominar o exame da proporcionalidade em toda a sua extensão. ${ }^{55}$

Relativamente ao fumus comissi delicti, Moraes destaca que o requerimento deverá trazer, com o maior grau de demonstração possível e por meios lícitos, todos os elementos aptos a indicar qual o crime tido como cometido em todas as suas circunstâncias e a demonstração robusta do nexo que relaciona um determinado e individualizado imputado àquele crime. Assim é que, no que se refere à materialidade, o juiz deverá consignar qual o tipo penal incidente ao caso, todas as circunstâncias de seu

do Supremo Tribunal Federal. Rel.: Min. Dias Toffoli. Julgamento em: 17 de dezembro de 2013; HC 169.331/RJ. Decisão Monocrática do Min. Gilmar Mendes do Supremo Tribunal Federal. Rel.: Min. Gilmar Mendes. Julgamento em: 3 de junho de 2019; HC 509.878/SP. Sexta Turma do Superior Tribunal de Justiça. Rel.: Min. Rogerio Schietti Cruz. Julgamento em: 05 de setembro de 2019; RHC 122.791/SP. Decisão Monocrática do Min. Nefi Cordeiro do Superior Tribunal de Justiça. Rel.: Min. Nefi Cordeiro. Julgamento em: 2 de março de 2020; Ag. Rg. HC 579.033/SP. Quinta Turma do Superior Tribunal de Justiça. Rel.: Min. Reynaldo Soares da Fonseca. Julgamento em: 16 de junho de 2020; HC 616.535/SP. Sexta Turma do Superior Tribunal de Justiça. Rel.: Min. Laurita Vaz. Julgamento em: $1^{\circ}$ de dezembro de 2020). Esta compreensão foi reforçada pela nova redação dos artigos 312 e 315 do Código de Processo Penal, dada pela Lei 13.964/2019. Após a alteração legislativa, o parágrafo $2^{\circ}$ do art. 312 passou a prever que «a decisão que decretar a prisão preventiva deve ser motivada e fundamentada em receio de perigo e existência concreta de fatos novos ou contemporâneos que justifiquem a aplicação da medida adotada». Por sua vez, o art. 315, depois de prescrever no caput que «a decisão que decretar, substituir ou denegar a prisão preventiva será sempre motivada e fundamentada», definiu em seu parágrafo segundo algumas hipóteses nas quais não se considera fundamentada qualquer decisão judicial, valendo destacar aquelas em que o magistrado ou tribunal «limitar-se à indicação, à reprodução ou à paráfrase de ato normativo, sem explicar sua relação com a causa ou a questão decidida» (inc. I); «empregar conceitos jurídicos indeterminados, sem explicar o motivo concreto de sua incidência no caso» (inc. II); «invocar motivos que se prestariam a justificar qualquer outra decisão» (inc. III); «limitar-se a invocar precedente ou enunciado de súmula, sem identificar seus fundamentos determinantes nem demonstrar que o caso sob julgamento se ajusta àqueles fundamentos» (inc. V).

MORAES, Maurício Zanoide. Decisão judicial..., op. cit., p. 295-296. 
cometimento, se o crime se dirigiu a alguma pessoa específica ou se foi de destino aleatório, se o crime se deu em decorrência de alguma situação específica que dispara no imputado uma agressividade específica. ${ }^{56}$

Já quanto à autoria, o juiz deve demonstrar, de modo claro e coerente, os elementos lícitos que, objetiva e diretamente, revelam que foi a conduta atribuível ao imputado que provocou o resultado típico, bem como individualizar cada um dos imputados em face de quem se requer medida cautelar, sendo inconstitucional proferir decisão com tratamento em grupo. ${ }^{57}$

Em resumo, ao tratar do fumus comissi delicti, Moraes argumenta que a decisão deve se ater, de modo aprofundado e específico, a detalhar aspectos fáticos específicos da materialidade e individualizar não apenas o comportamento de cada imputado, mas também suas características pessoais. ${ }^{58}$

No que diz respeito ao periculum libertatis, o autor realiza uma divisão entre a identificação de provável perigo com a liberdade do imputado e a identificação da medida cautelar apropriada ao perigo previamente definido. Nada obstante o segundo aspecto, ligado à regra da proporcionalidade, seja de extrema importância e possa demandar eventual juízo de suficiência probatória, parece-nos que o tema proposto neste trabalho está mais relacionado ao primeiro aspecto (perigo gerado pela plena liberdade do imputado).

Moraes sustenta que o julgador deverá verificar se foram identificados, com base fática própria e correlacionada ao imputado, elementos objetivamente demonstrados no procedimento/processo e indicativos do perigo provável a um também especificado bem jurídico. Em sua visão, portanto, a base fática que revela o perigo deve ser específica e não se exaure naquela base necessária e já exposta para atender à demonstração de materialidade e de autoria. Considerando que nem toda persecução

56 MORAES, Maurício Zanoide. Decisão judicial..., op. cit., p. 297.

57 MORAES, Maurício Zanoide. Decisão judicial..., op. cit., p. 297. Sobre necessidade de individualização, ver: CAPEZ, Rodrigo. Prisão e medidas cautelares diversas: a individualização da medida cautelar no processo penal. São Paulo: Quartier Latin, 2017.

58 MORAES, Maurício Zanoide. Decisão judicial..., op. cit., p. 298. 
penal necessita de medida cautelar, não é a verificabilidade por elementos de prova da materialidade e autoria que satisfazem o requisito da individualização do perigo derivado da liberdade do imputado. Sustenta o autor que, caso este perigo não esteja clara e coerentemente indicado com base empírica objetiva e própria, o pleito deve ser rechaçado. ${ }^{59}$

Em seguida, Moraes esclarece, mais detidamente, quais as características que esta base fática deve ter para definição do perigo. A nosso ver com acerto, o autor afirma que a materialidade e autoria são pontos referenciais, mas não reveladores do perigo. ${ }^{60}$ Sem embargo de que esta linha de raciocínio possa, ainda assim, revelar-se controversa em relação ao risco de reiteração delitiva, ${ }^{61}$ é inegável a importância de se destacar a exigência de base fática autônoma para identificação do perigo processual.

O tema, no entanto, não é simples. O Tribunal Europeu de Direitos Humanos, por exemplo, estabeleceu em algumas oportunidades que, para a decretação da prisão preventiva com fundamento no perigo de fuga, não basta a imputação de um crime grave, devendo-se levar em conta aspectos como o caráter do imputado, sua moral, residência, ocupação, bens, vínculos com o país em que é processado, laços familiares, contatos internacionais. ${ }^{62}$ Algumas dúvidas se apresentam: estes aspectos poderiam ser considerados uma base fática autônoma apta à definição de perigo com a liberdade do imputado? Se sim, como se estrutura o raciocínio que, partindo, por exemplo, da moral ou ocupação do imputado, infere um risco de fuga?

59 MORAES, Maurício Zanoide. Decisão judicial..., op. cit., p. 299.

60 MORAES, Maurício Zanoide. Decisão judicial..., op. cit., p. 300-301.

61 Ver: SÁNCHEZ-VERA GÓMEZ TRELLES, Javier. Variaciones sobre la presunción de inocencia: análisis funcional desde el Derecho penal. Madrid: Marcial Pons, 2012. p. 51-52.

62 TEDH. Caso Becciev v. Moldova (Ap. n. 9190/03), §58. Data: 4 de outubro de 2005. Disponível em: http://hudoc.echr.coe.int/fre?i=001-71889. Consultado em 27 de junho de 2021; TEDH. Caso Khodorkovskiy v. Russia (Ap. n. 5829/04), §185. Data: 31 de maio de 2011. Disponível em: http://hudoc. echr.coe.int/fre?i=001-104983. Consultado em 27 de junho de 2021; TEDH. Caso Yevgeniy Bogdanov v. Russia (Ap. 22405/04), §136. Data: 26 de fevereiro de 2015. Disponível em: http://hudoc.echr.coe.int/eng?i=001-152595. Consultado em 27 de junho de 2021. 
Atento à questão, Ferrer Beltrán argumenta só haver duas formas de realizar esta inferência. A primeira, a partir de uma generalização que diga que pessoas com determinada moral ou ocupação costumam fugir, o que leva ao problema de existência de estatísticas seguras e, no caso de elas existirem, de aplicação de uma informação estatística ao caso concreto. ${ }^{63}$ A segunda, com incorporação de uma premissa normativa em forma de presunção, estabelecendo que, se o imputado tiver determinada moral ou ocupação, deverá presumir-se que fugirá. Em relação a esta segunda possibilidade, Ferrer Beltrán questiona se é compatível com a presunção de inocência, por exemplo, presumir um risco de fuga de quem tem bens e contatos no exterior. E mais: como poderia o acusado provar o contrário? ${ }^{64}$

Em seguida, Ferrer Beltrán destaca a dificuldade de se provar um risco processual nos termos exigidos pela Comissão Interamericana de Direitos Humanos ${ }^{65}$, pela Corte Interamericana de Direitos Humanos ${ }^{66} \mathrm{e}$ pelo Tribunal Europeu de Direitos Humanos. ${ }^{67}$ Sublinha o autor, todavia, que esses requisitos podem ser cumpridos quando o imputado já tentou ou realizou ações preparatórias para fugir, destruir provas ou obstaculizar

63 FERRER BELTRÁN, Jordi. Presunción de inocencia y prisión preventiva. In: VÁZQUEZ, Carmen (coord.). Hechos y Razonamiento Probatorio. México: CEJI, 2018. p. 150-151. Sobre o problema de utilização de conhecimento estatístico: FERRER BELTRÁN, Jordi. La valoración..., op. cit., p. 98-108. FERRER BELTRÁN, Jordi. Presunción..., op. cit., p. 150-151. «A su vez, el riesgo procesal de fuga o de frustración de la investigación debe estar fundado en circunstancias objetivas. La mera alegación sin consideración del caso concreto no satisface este requisito.» (Comissão IDH. Informe n. 86/09, Caso 12.553, Jorge, José y Dante Peirano Basso, República Oriental del Uruguay, §85. Data: 6 agosto de 2009. Disponível em: https://www.cidh. oas.org/annualrep/2009sp/uruguay12553.sp.htm. Consultado em 27 de junho de 2021).

66 «Asimismo, ha destacado que el peligro procesal no se presume, sino que debe realizarse la verificación del mismo en cada caso, fundado en circunstancias objetivas y ciertas del caso concreto» (Corte IDH. Caso Norín Catrimán e otros v. Chile, §312. Fondo, Reparaciones y Costas. Sentencia de 29 de mayo de 2014. Disponível: https://www.corteidh.or.cr/docs/casos/ articulos/seriec_279_esp.pdf. Consultado em 28 de junho de 2021).

67 TEDH. Caso Smirnova v. Russia (Ap. n. 46133/99 e 48183/99), §56-64. Data:24 de outubro de 2003. Disponível em: http://hudoc.echr.coe.int/ fre?i=001-61262. Consultado em 27 de junho de 2021. 
a obtenção de provas. Para Ferrer Beltrán, o fato de que fora desses casos é difícil considerar-se provado suficientemente o risco processual ressalta a excepcionalidade da medida de prisão preventiva. ${ }^{68}$

No limite, e para os fins desse trabalho, este debate - de difícil resolução - revela a necessidade de se contar com uma determinada base fática para identificação do perigo decorrente da liberdade do acusado (periculum libertatis), a qual, em que pese possa ter a base fática da materialidade e autoria (fumus comissi delicti) como referência, não deve a ela se limitar.

Com efeito, a decisão judicial que decreta a prisão preventiva do imputado deve ser dividida em capítulos específicos que tratem dos pressupostos, requisitos e mérito da incidência, ou não, da medida cautelar de maneira lógica e racionalmente organizada. Relativamente ao fumus comissi delicti, a decisão deve possuir capítulo próprio em que a verificação da materialidade e da autoria seja descrita a partir de uma base fática com determinado grau de confirmação empírica, além de constar indicação das características da materialidade e da autoria, que poderão servir de referência para os capítulos seguintes. ${ }^{69}$

Por sua vez, em relação ao periculum libertatis, a decisão, fundada em elementos probatórios específicos, deverá identificar qual o perigo existente na conduta do imputado. Este perigo deverá relacionar-se com alguma das situações de perigo processual descritas na legislação (aplicação da lei penal etc.).

\section{Standards de PROVA E PRISÃo PREVEnTIVA.}

Antes de prosseguir com as análises e sugestões de específicos standards de prova para a prisão preventiva, convém esclarecer a dificuldade de se trabalhar, neste tema, com base na atual legislação processual.

Como visto, o tema dos standards de prova consiste em uma novidade tanto para a doutrina quanto para a jurisprudência brasileiras. Seria tão improvável quanto estranho que o legislador brasileiro tivesse

68 FERRER BELTRÁN, Jordi. Presunción..., op. cit., p. 151.

${ }^{69}$ MORAES, Maurício Zanoide. Decisão judicial..., op. cit., p. 300-301. 
assumido a vanguarda do debate e previsto, com rigor metodológico, os standards de prova necessários para a decisão sobre prisão preventiva.

São particularmente interessantes, portanto, as lições de Taruffo, no sentido de que, na ausência de normas ou princípios que determinem o standard de confirmação, a decisão sobre se um enunciado fático pode ser considerado adequadamente provado deve ser tomada segundo critérios racionais. ${ }^{70}$

Vale notar, todavia, que o legislador, ainda que por um golpe de intuição e sem a melhor terminologia, não deixou de fazer algum tipo de referência à prova necessária para identificação do fumus comissi delicti e do periculum libertatis. Por este motivo, a análise iniciará de forma descritiva, a partir da legislação processual penal e da interpretação que a doutrina brasileira tem feito dos dispositivos. A intenção é de identificar um critério político acerca do umbral de suficiência probatória.

A partir dessa análise inicial descritiva, procurar-se-á compatibilizar a atual interpretação doutrinária dos dispositivos com o que foi exposto acerca dos standards de prova. Seguindo este caminho, buscaremos propor standards de prova para a prisão preventiva. Muito embora possa haver boas razões para se aplicar de imediato estes standards de prova, é evidente que a conclusão estará mais próxima de uma proposta de lege ferenda.

\section{V.I. Standard de PROVA PARA O FUMUS COMISSI DELICTI.}

O art. 312 do CPP prevê que a prisão preventiva poderá ser decretada quando houver prova da existência do crime e indício suficiente de autoria.

Quanto à materialidade, a doutrina mais antiga interpretou a expressão «existência do crime» como sendo uma exigência da certeza da existência da infração. Nas palavras de Basileu Garcia: «[o] corpo de delito não autoriza dúvida. [...] requer-se a certeza da presença de um tipo legal de delito». ${ }^{71}$ Romeu Campos Barros, por sua vez, falava em «uma

70 TARUFFO, Michele. Uma simples..., op. cit., p. 253-254.

71 GARCIA, Basileu. Comentários ao Código de Processo Penal. Vol. 3. Rio de Janeiro: Revista Forense, 1945. p. 155. No mesmo sentido, citando Basileu 
realidade fática da qual não se tenha dúvida» e em exigência de «prova plena». ${ }^{72}$ A doutrina clássica brasileira, como se vê, sempre trabalhou com a ideia de certeza ou prova plena do crime como requisito para a decretação da prisão preventiva. ${ }^{73}$

A doutrina recente caminha no mesmo sentido. Conforme destaca Badaró, «[p]ara a decretação da prisão preventiva deverá haver certeza do cometimento do crime». ${ }^{74}$ Odone Sanguiné, por sua vez, afirma que a mencionada expressão «deve ser entendida como prova efetiva e cabal [...], exigindo-se prova, ou seja, a certeza da existência da materialidade do crime ${ }^{75}$ Zanoide de Moraes fala em «alto grau de probabilidade da materialidade», ${ }^{76}$ enquanto Ada Pellegrini Grinover, Antonio Magalhães Gomes Filho e Antonio Scarance Fernandes aludem à demonstração da «tipicidade do fato e sua real existência». ${ }^{77}$

Nota-se, portanto, que na interpretação da doutrina, clássica e contemporânea, o legislador brasileiro, em relação à materialidade para fins de identificação do fumus comissi delicti, optou por exigir um alto grau

Garcia: TUCCI, Rogério Lauria. Persecução Penal, Prisão e Liberdade. São Paulo: Saraiva, 1980. p. 237.

72 BARROS, Romeu Pires de Campos. Processo..., op. cit., p. 245.

73 Essa interpretação foi compartilhada pela jurisprudência, como se nota em: LOUREIRO JUNIOR, José. Conceito da prisão preventiva. São Paulo: Revista dos Tribunais, 1957. p. 38-42. Vale notar que, mesmo antes da edição do Código de Processo Penal de 1941, doutrina e jurisprudência já falavam em «prova plena do facto criminoso», como se observa em: MALTA, Tostes. Da prisão preventiva (Doutrina - Legislação - Jurisprudência) (1933). São Paulo: Saraiva \& Comp., 1935. p. 146-147.

74 BADARÓ, Gustavo Henrique. Ônus da Prova no Processo Penal. São Paulo: Editora RT, 2003. p. 424. Muito embora o autor em trabalhos mais recentes não venha mais trabalhando com a categoria certeza, é possível extrair do conceito a ideia de alto grau de confirmação empírica.

75 SANGUINÉ, Odone. Prisão cautelar, medidas alternativas e direitos fundamentais. Rio de Janeiro: Forense, 2014. p. 130.

76 MORAES, Maurício Zanoide de. Presunção de Inocência no Processo Penal Brasileiro: análise de sua estrutura normativa para a elaboração legislativa e para a decisão judicial. Rio de Janeiro: Lumen Juris, 2010. p. 374. No mesmo sentido: PEIXOTO, Ravi. Standards..., op. cit., p. 308.

77 GRINOVER, Ada Pellegrini; GOMES FILHO, Antonio Magalhães; FERNANDES, Antonio Scarance. As nulidades no processo penal. $6^{\mathrm{a}}$ ed. São Paulo: RT, 1999. p. 290. 
de confirmação empírica, muito semelhante ao exigido para a sentença penal condenatória.

A nosso juízo, tal interpretação é consoante às observações referentes à relação que deve existir entre os distintos standards de prova. Como visto, a tendência ascendente dos standards probatórios deve ser contrabalançada com a gravidade do erro para cada tipo de decisão. A prisão de um imputado antes do trânsito em julgado da sentença condenatória constitui grave intervenção na esfera dos seus direitos fundamentais. Considerando, ademais, que a definição de um standard probatório obedece a razões de ordem política, é fundamental levar-se em consideração as condições objetivas de nosso sistema penitenciário. ${ }^{78}$ Ademais, a dificuldade de se cumprir um standard de prova altamente exigente acerca da existência do crime, antes até da própria instrução probatória, parece-nos adequada à excepcionalidade da prisão preventiva.

78 Ao tratar da prisão preventiva na Colômbia, Alejandro Aponte Cardona observa que o juiz deve ter em conta, ao avaliar a necessidade, proporcionalidade, adequação e razoabilidade, as condições objetivas do regime carcerário colombiano (APONTE CARDONA, Alejandro. La detención preventiva en la nueva legislación procesal penal: hacia una prevalencia del principio de libertad (2005). In: Derecho Penal y Filosofía. Vol. I: Textos Escogidos. Bogotá: Grupo Editorial Ibáñez, 2014. p. 436). Vale notar que o Supremo Tribunal Federal já teve a oportunidade de declarar o «estado de coisas inconstitucional» do sistema penitenciário brasileiro (Medida Cautelar na ADPF 347/DF. Plenário do Supremo Tribunal Federal. Rel.: Min. Marco Aurélio. Julgamento em: 09 de setembro de 2015). Em diversas oportunidades a Corte IDH proferiu decisão requerendo a adoção de medidas provisórias no sistema carcerário brasileiro - Complexo Penitenciário do Curado (PE), Complexo Penitenciário de Pedrinhas (MA), Instituto Penal Plácido de Sá Carvalho (RJ) e Unidade de Internação Socioeducativa (UNIS/ES). O país, no entanto, continua sem adotar medidas eficazes de proteção à vida e à integridade de pessoas presas, motivo pelo qual a Corte IDH convocou, em junho de 2021, o país a responder sobre as recorrentes violações de direitos humanos no cárcere (ver: JUSTIÇA GLOBAL. Corte Interamericana questiona Estado brasileiro sobre recorrentes violações de direitos humanos no cárcere. Data: $1^{\text {o }}$ de junho de 2021. Disponível em: http://www.global.org.br/blog/corte-interamericana-questiona-estado-brasileiro-sobre-recorrentes-violacoes-de-direitos-humanos-no-carcere/. Consultado em 29 de junho de 2021). 
Assim, tomando de empréstimo as propostas oferecidas por Ferrer Beltrán, ${ }^{79}$ sugerimos o seguinte standard de prova para estabelecimento da materialidade para fins de identificação do fumus comissi delicti:

a) a hipótese de existência do crime deve ser capaz de explicar todos os dados disponíveis, integrando-os de forma coerente;

b) a hipótese deve refutar todas as demais hipóteses plausíveis explicativas dos mesmos dados que sejam compatíveis com a não existência do crime, excluídas as meras hipóteses ad hoc.

Relativamente à autoria, a doutrina clássica brasileira, cuidando da redação original do art. 312, interpretou a expressão «indícios suficientes de autoria» (no plural), no sentido de «probabilidade certa de autoria, e não simples possibilidade». ${ }^{80}$ Segundo Frederico Marques, verifica-se indícios suficientes de autoria quando «o réu é o provável autor do crime». ${ }^{81}$ Eduardo Espínola Filho definia como «indícios sérios, apontados ao paciente, sem probabilidade de erro». ${ }^{82}$

Tratando já da nova redação do art. 312, há na doutrina recente quem entenda a expressão «indício suficiente de autoria» (no singular) como exigência de uma «probabilidade veemente». ${ }^{83}$ Há ainda quem trabalhe com as noções de «probabilidade», ${ }^{84}$ «alto grau de probabilidade» ${ }^{85}$ e «forte probabilidade». .6

79 FERRER BELTRÁN, Jordi. Prueba sin..., op. cit., p. 209-210.

BARROS, Romeu Pires de Campos. Processo..., op. cit., p. 245. Semelhante opinião tinha Rogério Lauria Tucci, para quem não era possível confundir os indícios suficientes com «simples motivos de suspeita». (TUCCI, Rogério Lauria. Persecução..., op. cit., p. 237).

MARQUES, José Frederico. Elementos de Direito Processual Penal. Vol. IV (1961). $2^{\mathrm{a}}$ ed. Rio de Janeiro: Ed. Forense, 1965. p. 115.

ESPÍNOLA FILHO, Eduardo. Código de processo penal brasileiro anotado. Vol. III (1942). 5 ${ }^{\mathrm{a}}$ ed. Rio de Janeiro: Borsoi, 1960. p. 398.

SANGUINÉ, Odone. Prisão..., op. cit., p. 131.

BADARÓ, Gustavo Henrique. Ônus..., op. cit., p. 424.

MORAES, Maurício Zanoide de. Presunção..., op. cit., p. 374.

DELMANTO JUNIOR, Roberto. Liberdade e prisão no processo penal: as modalidades de prisão provisória e seu prazo de duração (1998). $3^{\mathrm{a}}$ ed. São Paulo: Saraiva, 2019. p. 308. 
Em que pese a ausência de unidade conceitual, a doutrina, seguindo a própria indicação do legislador, parece caminhar no sentido de exigir-se um grau menor de suficiência probatória para o estabelecimento da autoria, em comparação ao grau exigido para a materialidade, embora maior, ou pelo menos idêntico, do que aquele exigido para recebimento da denúncia. A nosso ver, parece correto o entendimento, à luz da tendência ascendente dos standards de prova e da própria cognição sumária que, prévia ao contraditório, tende a trabalhar com um acervo probatório ainda incompleto.

Nesse sentido, novamente tomando de empréstimo as propostas de Ferrer Beltrán, sugerimos o seguinte standard de prova para estabelecimento da autoria para fins de identificação do fumus comissi delicti:

a) a hipótese de autoria do crime pelo imputado deve ser a mais provavelmente verdadeira, à luz de todos os elementos existentes no procedimento/processo;

b) o conjunto de elementos juntados ao procedimento/processo deve ser o mais completo possível (excluídas as provas redundantes), considerando a fase processual e as circunstâncias do evento.

Por fim, seria conveniente que se adotasse, como já previsto por Calamandrei, um juízo em «dois tempos» em relação à identificação do fumus comissi delicti, logo após a participação, com possível juntada de novas provas (incluindo as provas sobre as provas), pela defesa do imputado. Como exposto, a adoção do mesmo standard de prova para decisões a serem tomadas com base em distintos conjuntos probatórios não significa a antecipação da decisão seguinte. A exigência de um juízo em «dois tempos» sobre o alcance ou não dos standards de prova para identificação do fumus comissi delicti parece-nos ter função distinta, seja pela especificidade, seja pela imediatez, da revisão obrigatória prevista no art. 316, parágrafo único, do CPP.

\section{V.II. Standards DE PROVA PARA O PERICULUM libertatis.}

Como visto, o tema do periculum libertatis desafia um sem-número de questões de difícil resolução. Por óbvio, não é possível provar um fato 
futuro. É possível, contudo, provar enunciados fáticos que permitam inferir (predizer) a prática de uma conduta futura. Esse raciocínio inferencial (complexo) não está livre de problemas, mas indica a necessidade de se contar com uma base fática para identificação do periculum libertatis. Assumindo-se, ademais, a imprescindibilidade de que essa base fática seja própria, isto é, independente da base fática do fumus comissi delicti, faz-se necessário pensar em standards de prova.

A nosso ver, essa cadeia inferencial deve conter no mínimo: (i) diversas inferências epistêmicas que, com base em elementos de informação/prova, apoiem cada um dos enunciados fáticos que, somados, servirão de apoio ao enunciado fático que deverá se encaixar na hipótese de periculum libertatis; (ii) uma inferência interpretativa cuja garantia é a definição de perigo/risco adotada pela doutrina, pela jurisprudência ou pelo legislador. ${ }^{87}{ }^{88}$ Assim, o enunciado fático que se pretende encaixar na hipótese de periculum libertatis deverá contar com um determinado grau de confirmação empírica a fim de atingir o standard de prova para o periculum libertatis.

$\mathrm{O}$ art. 312 do CPP prevê que a prisão preventiva poderá ser decretada quando houver indício suficiente de perigo gerado pelo estado de liberdade do imputado. O legislador se valeu, portanto, do mesmo conceito utilizado para a autoria no fumus comissi delicti.

Em geral, a doutrina clássica brasileira não dedicou grandes reflexões sobre a prova do periculum libertatis, talvez pela própria redação original do art. 313 do CPP (que tratava das hipóteses de perigo processual). Basileu Garcia falava, por exemplo, em «sérios sinais» de fuga. ${ }^{89}$ Sem aprofundar no debate e já tratando da nova redação do art. 312, dada pela Lei 5.349/67, Campos Barros argumentava a necessidade

87 Parece-nos que, na hipótese já vista de se aceitar apenas as tentativas ou ações preparatórias como aptas a identificar um perigo processual, esta segunda inferência perde substancial relevância, embora ainda possa existir, por exemplo, o problema do conceito de ação preparatória.

Sobre o tema, destacando a nem sempre clara distinção entre interpretação e prova: GONZÁLEZ LAGIER, Daniel. La inferencia probatoria. In: Quaestio Facti. Ensayos sobre prueba, causalidad y acción. Palestra-Temis: Lima-Bogotá, 2005. p. 61-62.

GARCIA, Basileu. Comentários..., op. cit., p. 163. 
de investigar a «previsão do perigo» «na sua inteireza», falando ora em «certeza do periculum in mora», ora em "probabilidade de perigo». ${ }^{90}$

A doutrina recente, por sua vez, defende a exigência de maior «carga de demonstração» do periculum libertatis, se comparado ao fumus comissi delicti. ${ }^{91}$ Odone Sanguiné fala em «juízo de certeza ou prova plena». ${ }^{92}$ Badaró, com mais argúcia, sustenta a necessidade de «prova plena dos fatos com base nos quais o juiz irá inferir o perigo do dano». ${ }^{93}$

A despeito do uso da expressão «indício suficiente» pelo legislador, parece-nos adequada a interpretação da doutrina brasileira recente no sentido de exigir o mais alto grau de confirmação empírica do enunciado fático (complexo) que se pretende encaixar em alguma das hipóteses de periculum libertatis. A uma, porque não é possível seguir a tendência ascendente dos standards de prova, na medida em que a análise do perigo se esgota no próprio provimento cautelar (ainda que exista a necessidade de revisão periódica). Não é possível, portanto, tomar-se como referência o standard de prova da sentença, como no caso do fumus comissi delicti. A duas, porque, como consequência do primeiro motivo, não existe a tendência de se incrementar o conjunto probatório durante o processo. Por fim, porque, como abordado acima, a prisão de um imputado antes do trânsito em julgado da sentença condenatória constitui uma grave intervenção na esfera dos seus direitos fundamentais.

Assim, outra vez a partir das propostas de Ferrer Beltrán, sugerimos o seguinte standard de prova para estabelecimento do enunciado fático que se pretende encaixar em alguma das hipóteses de periculum libertatis:

a) a hipótese do enunciado fático que será utilizado como base para inferir o periculum libertatis deve ser capaz de explicar todos os dados disponíveis, integrando-os de forma coerente;

b) a hipótese deve refutar todas as demais hipóteses plausíveis explicativas dos mesmos dados que sejam compatíveis com a não existência do enunciado fático, excluídas as meras hipóteses ad hoc.

\footnotetext{
90 BARROS, Romeu Pires de Campos. Processo..., op. cit., p. 240 e 249.

91 MORAES, Maurício Zanoide de. Presunção..., op. cit., p. 377; GOMES FILHO, Antonio Magalhães. Presunção..., op. cit., p. 79.

92 SANGUINÉ, Odone. Prisão..., op. cit., p. 136.

93 BADARÓ, Gustavo Henrique. Ônus..., op. cit., p. 429.
} 
Também aqui se fazem adequadas as considerações sobre um juízo em «dois tempos» em relação ao alcance ou não do standard de prova pela hipótese do enunciado fático (complexo) que servirá à identificação do periculum libertatis.

\section{Considerações finais.}

Assumindo-se que o melhor modelo para a valoração das provas no processo judicial é o da probabilidade lógica, é necessário reconhecer que o raciocínio judicial em matéria de fatos será sempre probabilístico e que nenhum conjunto probatório, por mais rico e completo que seja, permitirá certezas racionais. Daí a importância de se distinguir as fases de valoração das provas e decisão sobre os fatos a serem provados. Os standards de prova oferecem justamente critérios para a fase de decisão.

Não havendo espaço para automatismos, a decisão sobre cautelares pessoais no processo penal deve conter partes internas pré-definidas e de explicação judicial obrigatória e capítulos próprios para o fumus comissi delicti e o periculum libertatis. Em relação ao fumus comissi delicti, devem ser estabelecidos dois standards de prova: um para o requisito de materialidade, outro para o requisito de autoria. Já o periculum libertatis deve contar com base fática própria que permitirá chegar a um enunciado fático complexo que deverá se encaixar em uma das hipóteses legais de perigo processual, as quais exigem uma inferência interpretativa para sua conceituação. Este enunciado fático complexo deverá atingir também determinado standard de prova.

A partir dos requisitos metodológicos expostos, dos critérios atualmente oferecidos pelo legislador e pela interpretação que lhes vem sendo dada pela doutrina, oferecemos no texto, tomando de empréstimo as propostas de Jordi Ferrer Beltrán, os seguintes standards de prova para cada um desses requisitos:

1) Requisito de materialidade para identificação do fumus comissi delicti: a) a hipótese de existência do crime deve ser capaz de explicar todos os dados disponíveis, integrando-os de forma coerente; b) a hipótese deve refutar todas as demais hipóteses plausíveis explicativas dos mesmos dados que sejam compatíveis com a não existência do crime, excluídas as meras hipóteses ad hoc. 
2) Requisito de autoria para identificação do fumus comissi delicti: a) a hipótese de autoria do crime pelo imputado deve ser a mais provavelmente verdadeira, à luz de todos os elementos existentes no procedimento/ processo; b) o conjunto de elementos juntados ao procedimento/processo deve ser o mais completo possível (excluídas as provas redundantes), considerando a fase processual e as circunstâncias do evento.

3) Enunciado fático que se pretende encaixar em alguma das hipóteses de periculum libertatis: a) a hipótese do enunciado fático que será utilizado como base para inferir o periculum libertatis deve ser capaz de explicar todos os dados disponíveis, integrando-os de forma coerente; b) a hipótese deve refutar todas as demais hipóteses plausíveis explicativas dos mesmos dados que sejam compatíveis com a não existência do enunciado fático, excluídas as meras hipóteses ad hoc.

\section{REFERÊNCIAS}

ANDERSON, Terence; SCHUM, David; TWINING, William. Análisis de la prueba. Trad. coord. por Flavia Carbonell y Claudio Agüero. Madrid: Marcial Pons, 2015. ANDRÉS IBÁÑEZ, Perfecto. "Carpintaria” da Sentença Penal (em Matéria de "Fatos”). Trad. de Lédio Rosa de Andrade. In: Valoração da Prova e Sentença Penal. Rio de Janeiro: Lumen Juris, 2006. p. 119-162.

ANDRÉS IBÁÑEZ, Perfecto. Vicisitudes e itinerarios de la convicción probatoria en proceso penal. In: Prueba y convicción judicial en el proceso penal. Buenos Aires: Hammurabi, 2009. p. 27-72.

APONTE CARDONA, Alejandro. La detención preventiva en la nueva legislación procesal penal: hacia una prevalencia del principio de libertad (2005). In: Derecho Penal y Filosofía. Vol. I: Textos Escogidos. Bogotá: Grupo Editorial Ibáñez, 2014. p. 429-479.

ARANHA, Adalberto José Q. T. de Camargo. Da prova no processo penal (1983). $2^{a}$ ed. São Paulo: Saraiva, 1987.

BADARÓ, Gustavo Henrique. Epistemologia judiciária e prova penal. São Paulo: RT, 2019.

BADARÓ, Gustavo Henrique. Ônus da Prova no Processo Penal. São Paulo: RT, 2003. 
BALTAZAR JUNIOR, José Paulo. Standards Probatórios. In: KNIJNIK, Danilo (Org.). Prova Judiciária. Estudos sobre o novo direito probatório. Porto Alegre: Livraria do Advogado, 2007. p. 153-179.

BALTAZAR JUNIOR, José Paulo. Standards Probatórios no Processo Penal. Revista Jurídica, v. 363, p. 127-144, 2008.

BARROS, Romeu Pires de Campos. Processo Penal Cautelar (1982). 2a ed. Brasília: Gazeta Jurídica, 2017.

BARROS, Romeu Pires de Campos. Sistema do Processo Penal Brasileiro. Vol. I: Princípios Fundamentais do Processo Penal. Rio de Janeiro: Forense, 1987.

BINDER, Alberto M. Derecho Procesal Penal. Tomo V. Buenos Aires: Ad-Hoc, 2021.

CALAMANDREI, Piero. Introducción al estudio sistemático de las providencias cautelares (1936). Argentina: Ediciones Olejnik, 2018.

CALLARI, Francesco. The defendant's guilt beyond a reasonable doubt in the Italian criminal justice system. Revista Brasileira de Direito Processual Penal, Porto Alegre, vol. 7, n. 2, p. 1227-1260, mai./ago. 2021. https://doi.org/10.22197/ rbdpp.v7i2.577

CAPEZ, Rodrigo. Prisão e medidas cautelares diversas: a individualização da medida cautelar no processo penal. São Paulo: Quartier Latin, 2017.

CARLIZZI, Gaetano. Libero convincimento e ragionevole dubbio nel processo penale: storia prassi teoria. Bologna: Bonomo Editore, 2018.

CLERMONT, Kevin M. Standards of decision in law. Psychological and Logical Bases for the Standards of Proof, Here and Abroad. Durham: Carolina Academic Press, 2013.

COHEN, L. Jonathan. Lo probable y lo demostrable (1977). Trad. de Orión Vargas e Carlo Iván Ruiz. Medellín: Orión Vargas Vélez, 2017.

DAMAŠKA, Mirjan R. El derecho probatorio a la deriva (1997). Trad. de Joan Picó i Junoy. Madrid: Marcial Pons, 2015.

DEI VECCHI, Diego; CUMIZ, Juan. Estándares de suficiencia probatoria y ponderación de derechos: una aproximación a partir de la jurisprudencia de la Corte Penal Internacional. Madrid: Marcial Pons, 2019.

DELMANTO JUNIOR, Roberto. Liberdade e prisão no processo penal: as modalidades de prisão provisória e seu prazo de duração (1998). $3^{\text {a }}$ ed. São Paulo: Saraiva, 2019. 
DIAS, Jorge de Figueiredo. Direito Processual Penal (1974). Reimp. Coimbra: Coimbra Editora, 2004.

ESPÍNOLA FILHO, Eduardo. Código de processo penal brasileiro anotado. Vol. III (1942). 5a ed. Rio de Janeiro: Borsoi, 1960.

FERNANDES, Antonio Scarance. Teoria geral do procedimento e o procedimento no processo penal. São Paulo: RT, 2005.

FERRER BELTRÁN, Jordi. La valoración racional de la prueba. Madrid: Marcial Pons, 2007.

FERRER BELTRÁN, Jordi. Presunción de inocencia y prisión preventiva. In: VÁZQUEZ, Carmen (coord.). Hechos y Razonamiento Probatorio. México: CEJI, 2018. p. 137-165.

FERRER BELTRÁN, Jordi. Prova e verdade no direito (2003). Trad. de Vitor de Paula Ramos. São Paulo: RT, 2017.

FERRER BELTRÁN, Jordi. Prueba sin convicción: estándares de prueba y debido proceso. Madrid: Marcial Pons, 2021.

GARCIA, Basileu. Comentários ao Código de Processo Penal. Vol. III. Rio de Janeiro: Revista Forense, 1945.

GASCÓN ABELLÁN, Marina. Los hechos en el derecho. Bases argumentales de la prueba. $3^{\text {a }}$ ed. Madrid: Marcial Pons, 2010.

GASCÓN ABELLÁN, Marina. Sobre la posibilidad de formular estándares de prueba objetivos. In: VÁZQUEZ, Carmen (coord.). Hechos y Razonamiento Probatorio. México: CEJI, 2018. p. 67-80.

GOMES FILHO, Antonio Magalhães. A motivação das decisões penais (2001). $2^{\mathrm{a}}$ ed. rev. e atual. São Paulo: RT, 2013.

GOMES FILHO, Antonio Magalhães. Direito à prova no processo penal. São Paulo: RT, 1997.

GOMES FILHO, Antonio Magalhães. Presunção de inocência e prisão cautelar. São Paulo: Saraiva, 1991.

GONZÁLEZ LAGIER, Daniel. ¿Es posible formular un estándar de prueba preciso y objetivo? Algunas dudas desde un enfoque argumentativo de la prueba. In: FERRER BELTRÁN, Jordi; VÁZQUEZ, Carmen (eds.). El razonamiento probatorio en el proceso judicial. Un encuentro entre diferentes tradiciones. Madrid: Marcial Pons, 2020. p. 426-431. 
GONZÁLEZ LAGIER, Daniel. La inferencia probatoria. In: Quaestio Facti. Ensayos sobre prueba, causalidad y acción. Palestra-Temis: Lima-Bogotá, 2005. p. 53-107. GRINOVER, Ada Pellegrini; GOMES FILHO, Antonio Magalhães; FERNANDES, Antonio Scarance. As nulidades no processo penal. $6^{\mathrm{a}}$ ed. São Paulo: RT, 1999.

HOLLÄNDER, Pavel. Proof and Changing Idea of Truth in Legal Thinking: Reflection on Postmodernism. In: TICHÝ, Luboš (ed.). Standards of Proof in Europe. Alemanha: Mohr Siebeck, 2019. p. 3-18.

JUSTIÇA GLOBAL. Corte Interamericana questiona Estado brasileiro sobre recorrentes violações de direitos humanos no cárcere. Data: $1^{\circ}$ de junho de 2021. Disponível em: <http://www.global.org.br/blog/corte-interamericana-questiona-estado-brasileiro-sobre-recorrentes-violacoes-de-direitos-humanos-no-carcere/>. Acesso em: 29 de junho de 2021.

KNIJNIK, Danilo. A prova nos Juízes Cível, Penal e Tributário. Rio de Janeiro: Forense, 2007.

KNIJNIK, Danilo. Os standards do convencimento judicial: paradigmas para o seu possível controle. Revista Forense, v. 97, n. 353, p. 15-52, 2001.

LAUDAN, Larry. ¿Es razonable la duda razonable? (2003). Trad. de Jose R. Beguelin. In: El estándar de prueba y las garantías en el proceso penal. Buenos Aires: Hammurabi, 2011. p. 119-195.

LAUDAN, Larry. Por qué un estándar de prueba subjetivo y ambiguo no es un estándar (2005). Trad. de Raul Calvo Soler. In: El estándar de prueba y las garantías en el proceso penal. Buenos Aires: Hammurabi, 2011. p. 57-86.

LAUDAN, Larry. The Law's Flaws. Rethinking Trial and Errors? Milton Keynes: College Publications, 2016.

LOUREIRO JUNIOR, José. Conceito da prisão preventiva. São Paulo: RT, 1957.

MALTA, Tostes. Da prisão preventiva (Doutrina - Legislação - Jurisprudência) (1933). São Paulo: Saraiva \& Comp., 1935.

MARQUES, José Frederico. Elementos de Direito Processual Penal. Vol. II. Rio de Janeiro: Companhia Forense, 1961.

MARQUES, José Frederico. Elementos de Direito Processual Penal. Vol. IV (1961). $2^{\mathrm{a}}$ ed. Rio de Janeiro: Forense, 1965.

MATIDA, Janaina; VIEIRA, Antonio. Para além do BARD: uma crítica à crescente adoção do standard de prova "para além de toda a dúvida razoável” no processo 
penal brasileiro. Revista Brasileira de Ciências Criminais, vol. 156, ano 27, p. 221248, São Paulo, jun. 2019.

MENDES, Paulo de Sousa. Medida da Prova. In: MENDES, Paulo de Sousa; PEREIRA, Rui Soares (coord.). Prova Penal Teórica e Prática. Coimbra: Almedina, 2019. p. 19-40.

MITIDIERO, Daniel. Antecipação da Tutela: da tutela cautelar à técnica antecipatória (2013). $4^{\mathrm{a}}$ ed. São Paulo: RT, 2019.

MORAES, Maurício Zanoide. Decisão judicial e medidas cautelares pessoais: em busca de um modelo decisório ideal. In: VAZ, Denise Provasi et al. (orgs.). Eficiência e garantismo no processo penal: estudos em homenagem a Antonio Scarance Fernandes. São Paulo: LiberArs, 2017. p. 289-313.

MORAES, Maurício Zanoide de. Presunção de Inocência no Processo Penal Brasileiro: análise de sua estrutura normativa para a elaboração legislativa e para a decisão judicial. Rio de Janeiro: Lumen Juris, 2010.

NANZER, Alberto. La regularidad como derecho individual. Fundamentos para una teoría normativa del proceso penal. Madrid: Marcial Pons, 2021.

NARDELLI, Marcella Mascarenhas. Presunção de Inocência, Standards de Prova e Racionalidade das Decisões sobre os Fatos no Processo Penal. In: SANTORO, Antonio E. R.; MALAN, Diogo Rudge; MIRZA, Flávio (org.). Crise no Processo Penal Contemporâneo: escritos em homenagem aos 30 anos da Constituição de 1988. Belo Horizonte: D’Plácido, 2018. p. 289-309.

NOBILI, Massimo. Die freie richterliche Überzeugungsbildung (1974). Trad. de Thomas Vormbaum. Baden-Baden: Nomos Verlagsgesellschaft, 2001.

ORTEGA GOMERO, Santiago (dir.). Proceso, prueba y estándar. Lima: ARA. 2009. PÁEZ, Andrés (ed.). Discusiones XVIII: “Estándares de prueba”, nº 18, 2|2016, EDIUNS, 2018.

PÁEZ, Andrés (coord.). Hechos, evidencia y estándares de prueba. Ensayos de epistemología jurídica. Bogotá: Universidad de los Andes, 2015.

PALACIOS MOSQUERA, Luis Blaimir. Detención preventiva y control de convencionalidad: el "peligro para la comunidad" desde la perspectiva del Sistema Interamericano de Derechos Humanos. Bogotá: Grupo Editorial Ibáñez, 2018.

PEIXOTO, Ravi. Standards probatórios no direito processual brasileiro. Salvador: JusPodivm, 2021. 
PRADO, Geraldo. Excepcionalidade da prisão provisória. In: FERNANDES, Og (coord.). Medidas Cautelares no Processo Penal: Prisões e suas alternativas. Comentários à Lei 12.403, de 04.05.2011. São Paulo: Editora RT, 2011. p. 101-204.

SÁNCHEZ-VERA GÓMEZ TRELLES, Javier. Variaciones sobre la presunción de inocencia: análisis funcional desde el Derecho penal. Madrid: Marcial Pons, 2012.

SANGUINÉ, Odone. Prisão cautelar, medidas alternativas e direitos fundamentais. Rio de Janeiro: Forense, 2014.

SCHENK, Leonardo Faria. Cognição sumária: limites impostos pelo contraditório no processo civil. São Paulo: Saraiva, 2013.

SCHWEIZER, Mark. Beweiswürdigung und Beweismaß: Rationalität und Intuition. Leipzig: Mohr Siebeck, 2015.

TARUFFO, Michele. A motivação da sentença civil (1975). Trad. de Daniel Mitidiero, Rafael Abreu e Vitor de Paula Ramos. São Paulo: Marcial Pons, 2015.

TARUFFO, Michele. La prueba de los hechos (1992). Trad. Jordi Ferrer Beltrán. $4^{\mathrm{a}}$ ed. Madrid: Editorial Trotta, 2011.

TARUFFO, Michele. Uma simples verdade: o juiz e a construção dos fatos (2009). Trad. de Vitor de Paula Ramos. São Paulo: Marcial Pons, 2016.

TICHÝ, Luboš (ed.). Standards of Proof in Europe. Alemanha: Mohr Siebeck, 2019.

TORNAGHI, Hélio. Instituições de Processo Penal. Vol. IV. Rio de Janeiro: Companhia Editora Forense, 1959.

TRENTO, Simone. As cortes supremas diante da prova. São Paulo: RT, 2018.

TUCCI, Rogério Lauria. Persecução Penal, Prisão e Liberdade. São Paulo: Saraiva, 1980.

VASCONCELLOS, Vinicius Gomes de. A prova no processo penal: a importância da valoração do lastro probatório e de seu controle por meio recursal. Revista Eletrônica do Curso de Direito da UFSM, v. 13, n. 2, p. 695-721, 2018. https://doi. org/10.5902/1981369430012

VASCONCELLOS, Vinicius Gomes de. Standard probatório para condenação e dúvida razoável no processo penal: análise das possíveis contribuições ao ordenamento brasileiro. Revista Direito GV, v. 16, n. 2, p. 1-26, maio/ago 2020. http:// dx.doi.org/10.1590/2317-6172201961 
VÁZQUEZ, Carmen (ed.). Estándares de prueba y prueba científica. Ensayos de epistemología jurídica. Madrid: Marcial Pons, 2013.

VIEIRA, Renato Stanziola. Controle da Prova Penal: Obtenção e Admissibilidade. São Paulo: Editora RT, 2021.

VITALE, Gustavo L. Encarcelamiento de presuntos inocentes. Hacia la abolición de una barbarie. Buenos Aires: Hammurabi, 2007.

WATANABE, Kazuo. Da cognição no processo civil (1987). $2^{\text {a }}$ ed. atual. Campinas: Bookseller, 2000.

WHITMAN, James Q. The origins of reasonable doubt. Theological roots of the criminal trial. Yale University Press: New Heaven-London, 2008.

ZAZA, Carlo. Il ragionevole dubbio nella logica della prova penale. Milano: Giuffrè Editore, 2008.

\section{Additional information and author's declarations (scientific integrity)}

Acknowledgement: Agradeço a Malu Peres Bittencourt, Clarissa Diniz Guedes, Antonio Vieira e Pedro Muxfeldt pela gentil revisão do texto, com sugestões de forma e conteúdo, bem como aos revisores anônimos pelos apontamentos e críticas.

Conflict of interest declaration: the author confirms that there are no conflicts of interest in conducting this research and writing this article.

Declaration of authorship: all and only researchers who comply the authorship requirements of this article are listed as authors; all coauthors are fully responsible for this work in its entirety.

Declaration of originality: the author assures that the text here published has not been previously published in any other resource and that future republication will only take place with the express indication of the reference of this original publication; he also attests that there is no third party plagiarism or self-plagiarism. 


\section{Editorial process dates}

(http://www.ibraspp.com.br/revista/index.php/RBDPP/about/editorialPolicies)

- Submission: 15/07/2021

- Desk review and plagiarism check: 16/07/2021

- Review 1: 29/07/2021

- Review 2: 25/08/2021

- Preliminary editorial decision: 03/09/2021

- Correction round return 1:

- Preliminary editorial decision 2:

- Correction round return 2:

- Final editorial decision:

\section{Editorial team}

- Editor-in-chief: 1 (VGV)

- Associated-editor: 2 (BC, LG)

- Reviewers: 2

\section{HOW TO CITE (ABNT BRAZIL):}

BADARÓ MASSENA, Caio. Prisão preventiva e standards de prova: propostas para o processo penal brasileiro. Revista Brasileira de Direito Processual Penal, vol. 7, n. 3, p. 1631-1668, set./dez. 2021. https://doi.org/10.22197/rbdpp.v7i3.617

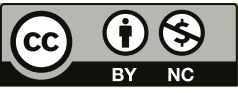

Esta obra está licenciada com uma Licença Creative Commons Atribuição-NãoComercial 4.0 Internacional. 